\title{
On improving cold region hydrological processes in the Canadian Land Surface Scheme
}

\author{
Arman Ganji $^{1} \cdot$ Laxmi Sushama $^{1} \cdot$ Diana Verseghy $^{2} \cdot$ Richard Harvey $^{2}$
}

Received: 11 November 2014 / Accepted: 24 August 2015 / Published online: 4 September 2015

(C) The Author(s) 2015. This article is published with open access at Springerlink.com

\begin{abstract}
Regional and global climate model simulated streamflows for high-latitude regions show systematic biases, particularly in the timing and magnitude of spring peak flows. Though these biases could be related to the snow water equivalent and spring temperature biases in models, a good part of these biases is due to the unaccounted effects of non-uniform infiltration capacity of the frozen ground and other related processes. In this paper, the treatment of frozen water in the Canadian Land Surface Scheme (CLASS), which is used in the Canadian regional and global climate models, is modified to include fractional permeable area, supercooled liquid water and a new formulation for hydraulic conductivity. The impact of these modifications on the regional hydrology, particularly streamflow, is assessed by comparing three simulations performed with the original and two modified versions of CLASS, driven by atmospheric forcing data from the European Centre for Medium-Range Weather Forecast (ECMWF) reanalysis (ERA-Interim) for the 1990-2001 period over a northeast Canadian domain. The two modified versions of CLASS differ in the soil hydraulic conductivity and matric potential formulations, with one version being based on formulations from a previous study and the other one is newly proposed. Results suggest statistically significant decreases in infiltration and therefore soil moisture during the snowmelt season
\end{abstract}

Arman Ganji

aganji@sca.uqam.ca

1 Centre ESCER (Étude et Simulation du Climat à l'Échelle Régionale), Université du Québec à Montréal, 201 Ave. President-Kennedy, Montreal QC H2X 3Y7, Canada

2 Climate Research Division, Environment Canada, Toronto, Canada for the simulation with the new hydraulic conductivity and matric potential formulations and fractional permeable area concept compared to the original version of CLASS, which is also reflected in the increased spring surface runoff and streamflows in this simulation with modified CLASS over most of the study domain. The simulated spring peaks and their timing in this simulation are also in better agreement to those observed. This study thus demonstrates the importance of treatment of frozen water for realistic simulation of streamflows.

\section{Introduction}

The Canadian Regional Climate Model (CRCM5; Martynov et al. 2013) has been applied in a number of studies to assess projected changes to streamflow characteristics, particularly for the high-latitude regions. The land surface model used in CRCM5 is the Canadian Land Surface Scheme (CLASS; Verseghy 2012), which is a physically based model. Studies that validated CRCM5/ CLASS simulated spring streamflows have reported systematic biases (Poitras et al. 2011; Huziy et al. 2012). For example, the study by Huziy et al. (2012) suggests underestimation of spring peak flows for the province of Quebec. Difficulties in capturing the timing of spring peak flows were also reported in this study. These could be due to biases in the simulated winter precipitation and therefore snow water equivalent (SWE) and/or spring temperatures or due to simplified representation of land processes such as the frozen soil scheme in the model. For instance, not all land surface schemes take into account the possibility of having permeable and impermeable patches in a grid cell under frozen conditions. Stähli et al. (2001) demonstrated the important role of soil 
freezing-induced water redistribution on winter and spring runoffs using a land surface model with and without permeable fractional areas. Niu and Yang (2006) demonstrated significant improvements in the Community Land Model version 2.0 (CLM2.0) simulated spring streamflows with the inclusion of fractional permeable area during frozen soil conditions (i.e. partitioning the model grid into permeable and impermeable parts), representation of supercooled soil water (i.e. coexistence of liquid water with ice in the soil over a wide range of temperatures below $0{ }^{\circ} \mathrm{C}$ ) through the freezing point depression equation and modified hydraulic conductivity formulation for frozen ground. According to Niu and Yang (2006), lack of representation of the above processes in the frozen soil scheme for their study regions led to low infiltration during snowmelt, leading to earlier and higher than observed springtime flows. Several other studies (Shanley and Chalmers 1999; Koren et al. 1999; Nyberg et al. 2001; Lindstrom et al. 2002; Cherkauer and Lettenmaier 2003; Bayard et al. 2005; Frampton et al. 2011) have also demonstrated the need to represent realistically frozen soil characteristics/processes to obtain realistic spring flows.

The main objective of this paper is to improve representation of the treatment of frozen water and thus runoffs and streamflow in CLASS by incorporating fractional permeable area, supercooled soil water, as suggested by Niu and Yang (2006), and a more realistic hydraulic conductivity formulation for frozen soil. Three simulations, one with the original and two with modified versions of CLASS, spanning the 1990-2001 period, are performed over a domain covering 21 selected northeast Canadian watersheds spread mainly across the province of Quebec and extending to some parts of Ontario and Newfoundland and Labrador provinces; the two modified versions of CLASS differ in their hydraulic conductivity and soil matric potential formulations which are discussed in details in Section 2. The study domain considered here is very important for hydroelectric power generation with almost $96 \%$ of the total energy produced in the province of Quebec being hydro-based and therefore important for the economy of the province. A large number of hydro-related impact and adaptation studies for the region, in the context of a changing climate, rely on climate model outputs, including streamflows. Therefore, it is important to model streamflows realistically in climate models to have higher confidence in future projections. CRCM5 with CLASS as the land surface scheme and WATROUTE as the routing scheme is commonly used over the region and the proposed modifications to the treatment of frozen water are expected to improve the timing and magnitude of streamflows, particularly spring peak flows.

The article is organized as follows. An overview of the CLASS/WATROUTE framework and details of the experimental domain are provided in Section 2. Section 3 covers the theoretical basis of all methodologies related to fractional permeable areas, hydraulic conductivity and freezing point depression formulations for frozen soils considered in this article. Results from various experiments are presented in Section 4, followed by a brief summary of the results and conclusions in Section 5.

\section{Model and experimental domain}

\subsection{CLASS/WATROUTE system}

The basic function of the land surface scheme CLASS is to integrate the energy and water balances of the land surface forward in time from an initial starting point, making use of atmospheric forcing data to drive the simulation (Verseghy et al. 1993; Verseghy 2012). As the first approximation to subgrid-scale variability, CLASS adopts a "pseudo-mosaic" approach and divides the land fraction of each grid cell into a maximum of four sub-areas: bare soil, vegetation, snow over bare soil and snow with vegetation. The energy and water budget equations are first solved for each sub-area separately and then averaged over the grid cell, using averaged structural attributes and physiological properties of the four plant functional types (PFTs) in CLASS: needleleaf trees, broadleaf trees, crops and grasses. These structural attributes include leaf area index (LAI), roughness length, canopy mass and rooting depth, which have to be specified if they are present in a grid cell.

CLASS uses three soil layers, $0.1,0.25$ and $3.75 \mathrm{~m}$ thick in its standard formulation. The latest version of CLASS that is used in this study has a flexible soil-layering scheme, i.e. the total soil depth and the thickness of soil layers can be varied as desired. Since parts of the study region considered in this article are underlain by continuous/discontinuous permafrost, the soil depth is chosen to be $30 \mathrm{~m}$ with 20 soil layers to avoid inaccuracies stemming from the zero heat flux boundary condition at the lower model boundary. The thicknesses of the soil layers from top to bottom are $0.1,0.2,0.3$ and $0.4 \mathrm{~m}$ followed by 0.5 -m-thick layers. It must be noted that the hydrology calculations are performed only for soil layers above bedrock. In CLASS, the surface runoff for the modelled area is estimated from the excess ponded water, which varies with the land surface type. For example, for forested land, thresholds of $10 \mathrm{~mm}$ are used for ponded depth, above which runoff is generated. Free vertical drainage is assumed at the lower boundary of the permeable part of soil column, which is the sub-surface runoff. The CLASS-simulated total runoff (surface and sub-surface) is transformed into streamflows using the modified routing model WATROUTE (Soulis et al. 2000; Poitras et al. 2011). The routing scheme solves the water 
balance equation at each grid cell and relates the water storage to outflow from the grid cell using Manning's equation. The routing model includes a groundwater reservoir, which is modelled as a linear reservoir as proposed in Sushama et al. (2004) and CLASS-simulated sub-surface runoff is used as input for the groundwater reservoir.

\subsection{Experimental domain and geophysical fields}

The simulations were done for the land points of a $135 \times 125$ point grid covering 21 watersheds located in the north-east part of Canada (Fig. 1a). All CLASS simulations are driven by atmospheric forcing data (i.e. precipitation rate, air temperature, wind speed, air humidity, incoming shortwave and longwave radiation) taken from the lowest model level of the European Centre for Medium-Range Weather Forecast (ECMWF) reanalysis (ERA-Interim; Dee et al. 2011). The reanalysis data is available at 6-hourly time interval, which is linearly interpolated to the model 30-min time-step and resolution. The soil type, i.e. percentage of sand and clay, shown in Fig. 1b, c for the study area is derived from the ECOCLIMAP database (FAO 2006). Figure 1d shows the depth to bedrock obtained from Webb et al. (1991) for the study area, which is an important parameter in CLASS as the hydrological budget is done only for layers above the bedrock. The fractional coverage of the four PFTs is taken from the 1-km high-resolution USGS Global Land Cover Characteristics (USGS-GLCC) data set.

The watershed delineation, digital river network channel lengths and slopes required by the routing scheme at the model resolution of $0.44^{\circ}$ are derived, following Huziy et al. (2012), based on the HydroSHEDS database (Lehner et al. 2008) that is available at 30-s resolution on latitude-longitude grid. In this study, WATROUTE uses daily time-steps and therefore runoff simulated by CLASS every $30 \mathrm{~min}$ are aggregated to daily intervals for use in WATROUTE for streamflow simulation.

\section{Methodology}

As mentioned earlier, this paper focuses on improving the treatment of frozen water in CLASS with a view to improving simulated streamflows. Accordingly, three simulations are performed over the study domain: EXP-1 using CLASS with its original formulations, EXP-2 using CLASS with fractional permeable area, hydraulic conductivity and freezing point depression modifications as in Niu and Yang (2006) and EXP-3 using CLASS with a newly proposed parameterization for hydraulic conductivity and using fractional permeable area concept and supercooled liquid water as in EXP-2. The theoretical bases of all approaches are discussed in the section below. The initial soil conditions (i.e. soil moisture and temperature) were obtained by spinning up CLASS for 100 years using atmospheric forcing data from ERA-Interim for the 1971-1980, repeatedly, followed by a simulation for the 1971-2001 period and the results are analysed and presented in this article for the 1990-2001 period.

\subsection{Theoretical bases}

\subsubsection{Experiment EXP-1}

In the original version of CLASS, an effective hydraulic conductivity $\left(k_{t}\right)$ is calculated for each soil layer, applying an empirical correction for the presence of frozen water content (Verseghy 2012) as:

$k=f_{\text {ice }} k_{\text {sat }} \cdot\left(\frac{\theta_{\text {liq }}}{\theta_{\text {sat }}}\right)^{2 b+3}$

where $\theta_{\text {liq }}$ is the liquid water content $\left(\mathrm{m}^{3} / \mathrm{m}^{3}\right), \theta_{\text {sat }}$ is the saturated water content $\left(\mathrm{m}^{3} / \mathrm{m}^{3}\right), k_{\text {sat }}(\mathrm{m} / \mathrm{s})$ is the saturated hydraulic conductivity and $b$ is the Clapp and Hornberger (1978) empirical parameter. In this equation, the ice content factor, $f_{\text {ice}}$, is calculated following Zhao and Gray (1997) as:

$f_{\text {ice }}=\left[1-\min \left(1.0, \frac{\theta_{\text {ice }}}{\theta_{\text {sat }}}\right)\right]^{2}$

where $\theta_{\text {ice }}$ is the frozen water content $\left(\mathrm{m}^{3} / \mathrm{m}^{3}\right)$. Zhao and Gray (1997) developed this ice content factor for the case of frozen silty clay loam. Since the ratio of silty to sandy impedance factors is between 10e-3 and 10e-5 (Luthdin 1990), using Eq. (2) can lead to overestimation of effective hydraulic conductivity for the case of coarse-textured soil, which will lead to underestimation of runoff and therefore streamflow for frozen ground conditions.

The relation between soil moisture and soil matric potential in CLASS follows Campbell (1974) and Clapp and Hornberger (1978):

$\psi_{t}=\psi_{\text {sat }}\left(\frac{\theta_{\text {liq }}}{\theta_{\text {sat }}}\right)^{-b}$

where $\psi_{t}$ and $\psi_{\text {sat }}$ are the un-saturated and saturated soil matric potentials $(m)$, respectively.

\subsubsection{Experiment EXP-2}

In this experiment, following Niu and Yang (2006), fractional permeable area and super-cooled soil water are introduced in CLASS. The water flux within the soil $(q)$, in the presence of 


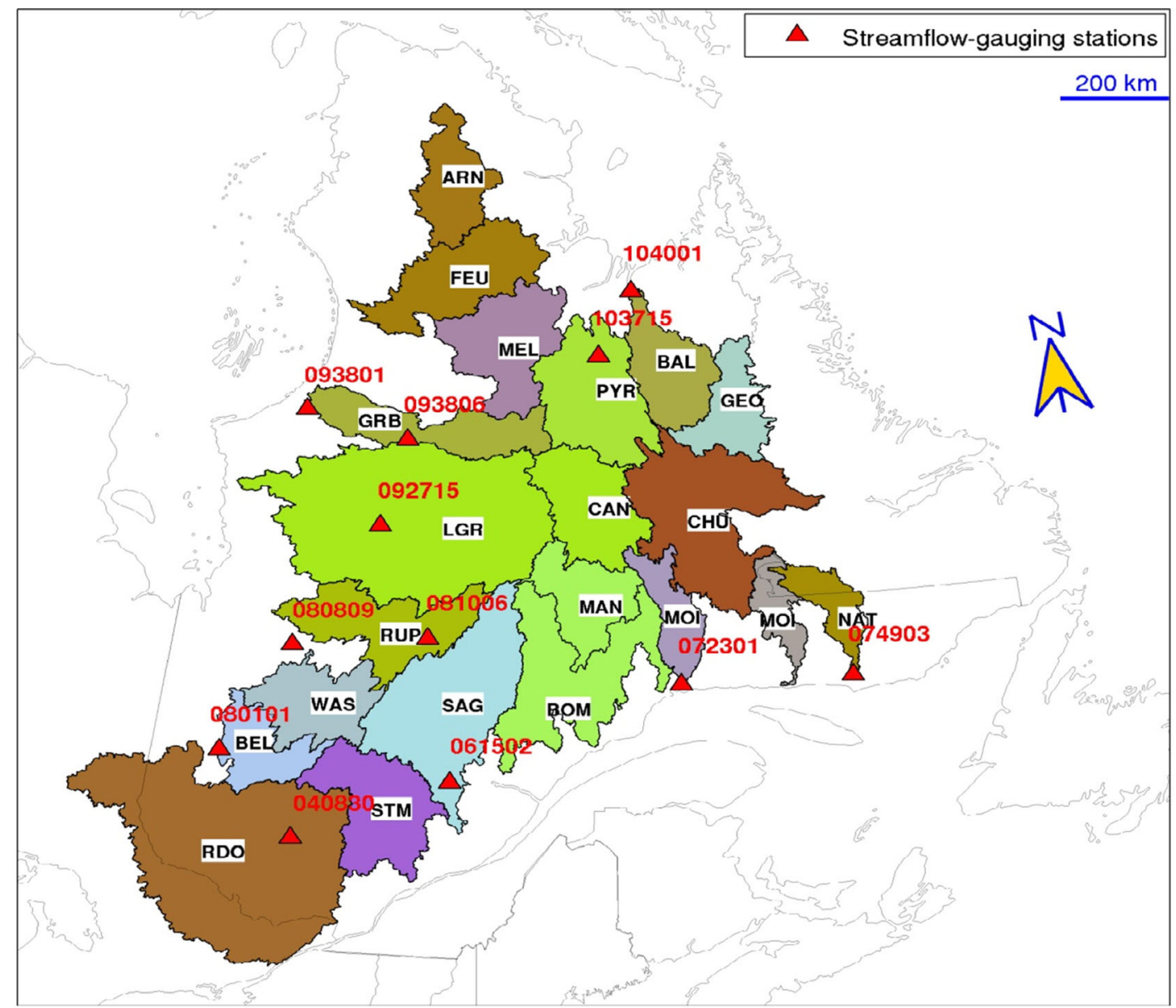

(a)

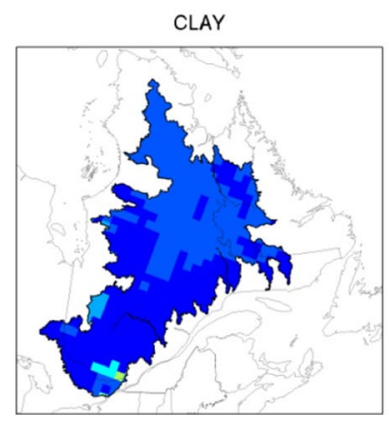

(b)

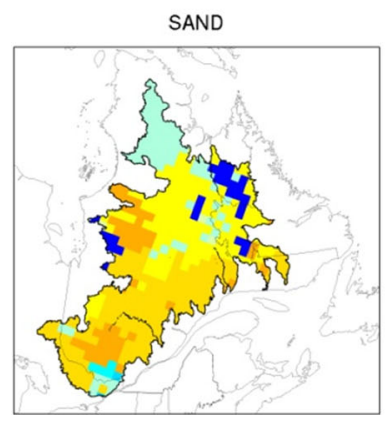

(c)

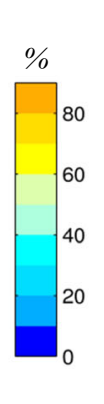

(c)

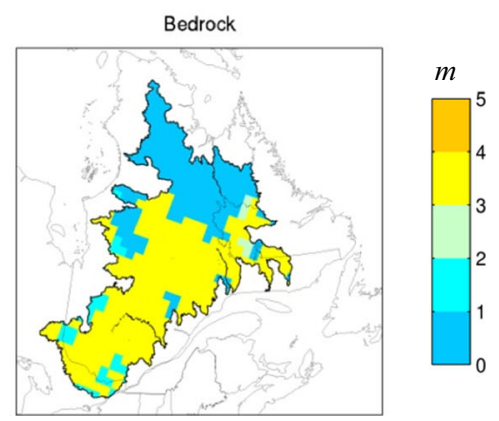

(d)

Fig. 1 a Study domain comprising of 21 watersheds; watershed details are provided in Table 1. The 12 gauging stations used in the evaluation of CLASS/WATROUTE simulated streamflows are also shown in the figure

(using red triangles) and in Table 1. Percentage of sand and clay and depth to bedrock for the study domain are shown in (b), (c) and (d)

developed by Koren et al. (1999) and Niu and Yang (2006) as:

$F_{\text {frz }}=e^{-a\left(1-\frac{\theta_{\text {ice }}}{\theta_{\text {sat }}}\right)}-e^{-a}$

where $\alpha$ is 3. Niu and Yang (2006) assumed that both the fractional permeable and impermeable zones share the same total soil moisture content of the grid cell. 
With these assumptions, the hydraulic conductivity and matric potential within a grid can be expressed as:

$$
\begin{aligned}
& k=\left(1-F_{\text {frz }}\right) k_{i}=\left(1-F_{\text {frz }}\right) k_{\text {sat }} \cdot\left(\frac{\theta_{\text {liq }}+\theta_{\text {ice }}}{\theta_{\text {sat }}}\right)^{2 b+3} \\
& \psi=\psi_{\text {sat }}\left(\frac{\theta_{\text {liq }}+\theta_{\text {ice }}}{\theta_{\text {sat }}}\right)^{-b}=\psi_{\text {sat }}\left(\frac{\theta}{\theta_{\text {sat }}}\right)^{-b}
\end{aligned}
$$

The upper limit of the liquid water content $\left(\theta_{\text {liq }}^{*}\right)$ for subfreezing temperatures proposed in Niu and Yang (2006) is:

$\theta_{\mathrm{liq}}^{*}=\theta_{\mathrm{sat}}\left\{\frac{10^{3} L_{f}\left(T-T_{\mathrm{frz}}\right)}{\vartheta T \psi}\right\}^{-\frac{1}{b}}$

where $L_{f}$ is the latent heat of fusion $(\mathrm{J} / \mathrm{Kg}), g$ is the gravitational acceleration $\left(\mathrm{m} / \mathrm{s}^{2}\right), T$ is the soil temperature $\left({ }^{\circ} \mathrm{C}\right)$ and $T_{\text {frz }}$ is the freezing point $\left({ }^{\circ} \mathrm{C}\right)$.

\subsubsection{Experiment EXP-3}

Equations (6) and (7) above assumed soil matric potential as a function of total soil moisture content which is the sum of total liquid and frozen water contents. This definition of soil matric potential is not appropriate for the case of frozen soil. Frozen water acts strikingly similar to the matrix of an unfrozen soil in terms of matric potential (Spaans and Baker 1996). As soils dry, water is removed and replaced by air, leaving the remaining water at an increasingly lower matric potential. The same process occurs in soils that freeze, except that liquid water changes phase and becomes ice. Thereby, the same force that prevents soil water from draining in unfrozen soil also prevents it from draining in frozen soil. Following Kulik (1978), Farkouki (1981) and Koren et al. (1999) proposed a modified version of Clapp and Hornberger's (1978) equation for matric potential, which is used in this experiment:

$\psi=\psi_{\text {sat }}\left(\frac{\theta_{\text {liq }}}{\theta_{\text {sat }}}\right)^{-b}\left(1+C_{k} \theta_{\text {ice }}\right)^{2}$

where $C_{k}$ is a constant value that represents the effects of soil and ice-specific surface on matric potential. Following Kulik (1978), Farkouki (1981) and Koren et al. (1999), $C_{k}=8$ is used in this study. Kulik (1978) experimentally showed that this value correctly represents the effect of increased specific surface of soil minerals on $\psi$ due to the presence of ice under frozen conditions.

As for effective hydraulic conductivity, Eq. (6) is used but with modified $K_{i}$ as

$k_{i}=k_{\mathrm{sat}} \cdot\left(\frac{\theta_{\mathrm{liq}}}{\theta_{\mathrm{sat}}}\right)^{2 b+3}\left(1+C_{k} \theta_{\mathrm{ice}}\right)^{-4}$
The above equation is derived using the approach of Campbell (1974) who estimated unsaturated hydraulic conductivity directly from a moisture retention function (i.e. Eq. (3)) using an integral equation that defines hydraulic conductivity as a function of pore radii. The details of the derivation of Eq. (10) are presented in Appendix I. As indicated earlier, this experiment also includes supercooled soil water, represented by Eq. (8), but with the modified matric potential (Eq. (9)).

Prior to studying the impact of various formulations discussed above on streamflows and other soil hydrological characteristics, the ERA-Interim data used for driving CLASS is validated to know what fraction of the biases in simulated streamflows can be attributed to biases in the driving data. To this end, the ERAInterim seasonal mean temperature and precipitation (Dee et al. 2011) are compared to the gridded observation-based data from the Climate Research Unit (CRU) (Mitchell and Jones 2005) and University of Delaware (UDEL) (Willmott and Matsuura 1995) for the 1990-2001 period (see Section 4.1).

The simulated snow water equivalent (SWE), soil water content, surface and sub-surface runoff and streamflows in the three simulations EXP-1, EXP-2 and EXP-3 are then compared to understand the impact of various formulations. The streamflows are derived from runoff of respective experiments using WATROUTE. Modelled streamflows are compared to those observed at 15 stream-gauging stations. The location of the gauging stations considered in this study is shown in Fig. 1a and details are provided in Table 1. The observed streamflows for these stations were obtained from the CEHQ (Centre d' expertise hydrique du Quebec) dataset. It must be noted that these stations selected for validation purpose are minimally regulated and provide a good coverage of the study domain.

For northern parts of the study domain, observed snowmelt hydrographs generally have steeper rising limbs because of the low permeability of frozen soil. The proposed modification of hydraulic conductivity used in EXP-3 is expected to increase the steepness of the modelled rising limb of snowmelt hydrographs through increased runoff. This modification may also alter the recession limb indirectly by changing soil moisture, saturated/unsaturated water flows in the soil matrix and infiltration rate.

Well known evaluation criteria such as the peak-weighted root mean square error (P-RMSE), proposed by the United State Army Corps of Engineers (United States Army Corps of Engineers 2000), Peak Error (PE; Das et al. 2008) and weighted NashSutcliffe efficiency coefficient (NS; Nash and Sutcliffe 1970; Hundecha et al. 2007) are used to compare observed and simulated streamflows. P-RMSE is the weighted mean of squared differences between simulated and observed flows, with the weights being proportional to the streamflow magnitudes:

$\mathrm{P}-\mathrm{RMSE}=\sum_{i=1}^{n} \frac{\left(Q_{\mathrm{oi}}-Q_{\mathrm{si}}\right)^{2}}{\overline{Q_{o}}}\left(\frac{w_{i}}{n}\right)$ 
where $Q_{\mathrm{oi}}$ and $Q_{\mathrm{si}}$ are the observed and simulated daily streamflows, respectively, $\overline{Q_{o}}$ is mean observed daily streamflow and $n$ is the total number of days. The range of P-RMSE is 0-Inf with smaller values corresponding to better performance. The weighting factor $\left(w_{i}\right)$ in Eq. (11) is given by:

$w_{i}=\frac{\left(Q_{\mathrm{oi}}+\overline{Q_{o}}\right)}{2 \overline{Q_{o}}}$

Criterion PE measures the relative difference between the mean annual simulated and observed peak flows:

$\mathrm{PE}=\frac{\bar{Q}_{s(\text { peak })}-Q_{0(\text { peak })}}{\bar{Q}_{0(\text { peak })}}$

where $\bar{Q}_{s}$ (peak) and $\bar{Q}_{0}$ (peak) are the mean annual simulated and observed peak streamflows, respectively.

The NS index is defined as one minus the sum of the absolute squared differences between the simulated and observed flows, normalized by the variance of observed flows:

$\mathrm{NS}=1-\frac{\sum_{i=1}^{n} w_{i}\left(Q_{\mathrm{si}}-Q_{\mathrm{oi}}\right)^{2}}{\sum_{i=1}^{n} w_{i}\left(Q_{\mathrm{si}}-\overline{Q_{o}}\right)^{2}}$

where the weighting factor $\left(w_{i}\right)$ is estimated in a similar manner as the P-RMSE index.

\section{Results and discussion}

\subsection{Driving data validation}

The mean precipitation and temperature differences between ERA-Interim and the observation-based climate research unit (CRU) are compared in (Fig. 2) for the period 1990-2001 for the winter and spring seasons, as these are important for spring streamflows. ERA-Interim seasonal temperatures (DJF and MAM) are slightly warmer (by $1-2{ }^{\circ} \mathrm{C}$; Fig. 2a) compared to CRU over most watersheds. Furthermore, compared to CRU, ERA-Interim slightly overestimates the seasonal precipitation (by less than $1.5 \mathrm{~mm} /$ day) in the southern parts of the study domain (Fig. 2b) for MAM. No significant differences are noted for the other regions. Comparison with UDEL also suggests similar overestimation of both temperature and precipitation, in general. Small underestimations in seasonal temperatures over central regions are however noted over a few grid cells in the comparison with UDEL.

The positive temperature biases in ERA-Interim during DJF can lead to underestimation of SWE and thus have an impact on the simulated magnitudes of peak flows. Similarly, positive temperature biases during MAM can lead to earlier snowmelt and thus lead to biases in the timing of simulated streamflows. However, since the temperature biases in ERAInterim are generally in the +2 to -2 range, except for some isolated grid cells, it can be hypothesized that improving the treatment of frozen water can indeed improve the quality of simulated flows.

\subsection{Comparison of experiments}

Biases in the snow water equivalent (SWE) in CLASS can have a huge impact on spring streamflows. The biases in SWE are therefore estimated by comparing maximum monthly SWE for the December-May period from different simulations, i.e. EXP-1, EXP-2 and EXP-3, with two gridded SWE products - GlobSnow (Global Snow Monitoring for Climate Research; Luojus et al. 2010) and CMC (the Canadian Meteorological Centre; Brown and Brasnett 2010) datasets. It must be noted that the GlobSnow product is derived from a combination of ground-based data and satellite microwave radiometer-based measurements, while CMC dataset is obtained from surface synoptic observations and meteorological aviation reports.

The maximum monthly values of SWE for the DecemberMay period for EXP-1, EXP-2 and EXP-3 are compared with observed datasets in (Fig. 3a, b). The shaded areas in Fig. 3b

Table 1 Description of the 21 watersheds and the gauging stations considered in the study area

\begin{tabular}{lll}
\hline Watershed & Abbreviated name & Stations \\
\hline Rivière Arnaud & ARN & - \\
Rivière à la Baleine & BAL & 104001 \\
Rivière Bell & BEL & 080801 \\
Complexe Bersimis-Outardes-Manic & BOM & - \\
Réservoir Caniapiscau & CAN & - \\
Réservoir Chutes Churchill & CHU & - \\
Rivière aux Feuilles & FEU & - \\
Rivière George & GEO & - \\
Grande Rivière de la Romaine & GRB & 093801 \\
093806 & & \\
Complexe La Grande Rivière Sud & LGR & 092715 \\
Réservoir Manicouagan & MAN & - \\
Rivière aux Melzèzes & MEL & - \\
Réservoir Moise & MOI & 072301 \\
Rivière Natashquan & NAT & 074903 \\
Rivière Canispiscau & PYR & 103715 \\
Rivière des Outaouais & RDO & 040830 \\
Rivière Romaine & ROM & - \\
Rivière Rupert & RUP & 081006 \\
Lac Saint-Jean & SAG & 061502 \\
Rivière St-Maurice & STM & - \\
Rivière Waswanapi & WAS & 080809 \\
\hline
\end{tabular}


(a)
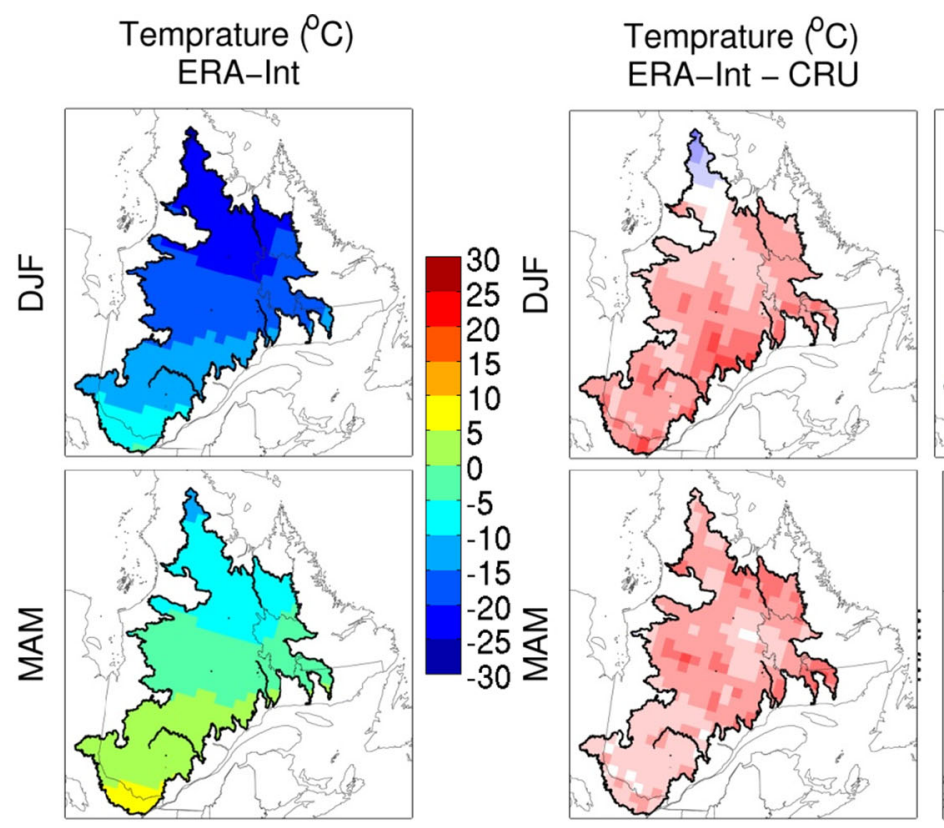

Temprature $\left.{ }^{\circ} \mathrm{C}\right)$

ERA-Int - UDel

\section{Precipitation ( $\mathrm{mm} /$ day) ERA-Int}

\section{Precipitation ( $\mathrm{mm} /$ day) Precipitation ( $\mathrm{mm} /$ day) ERA-Int - CRU}

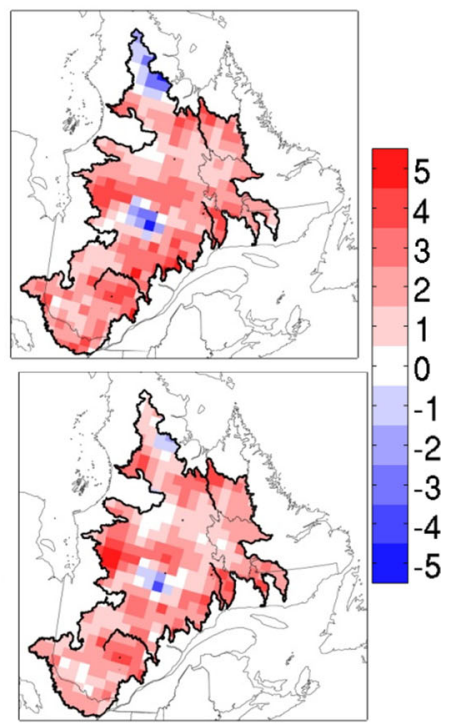

(b)
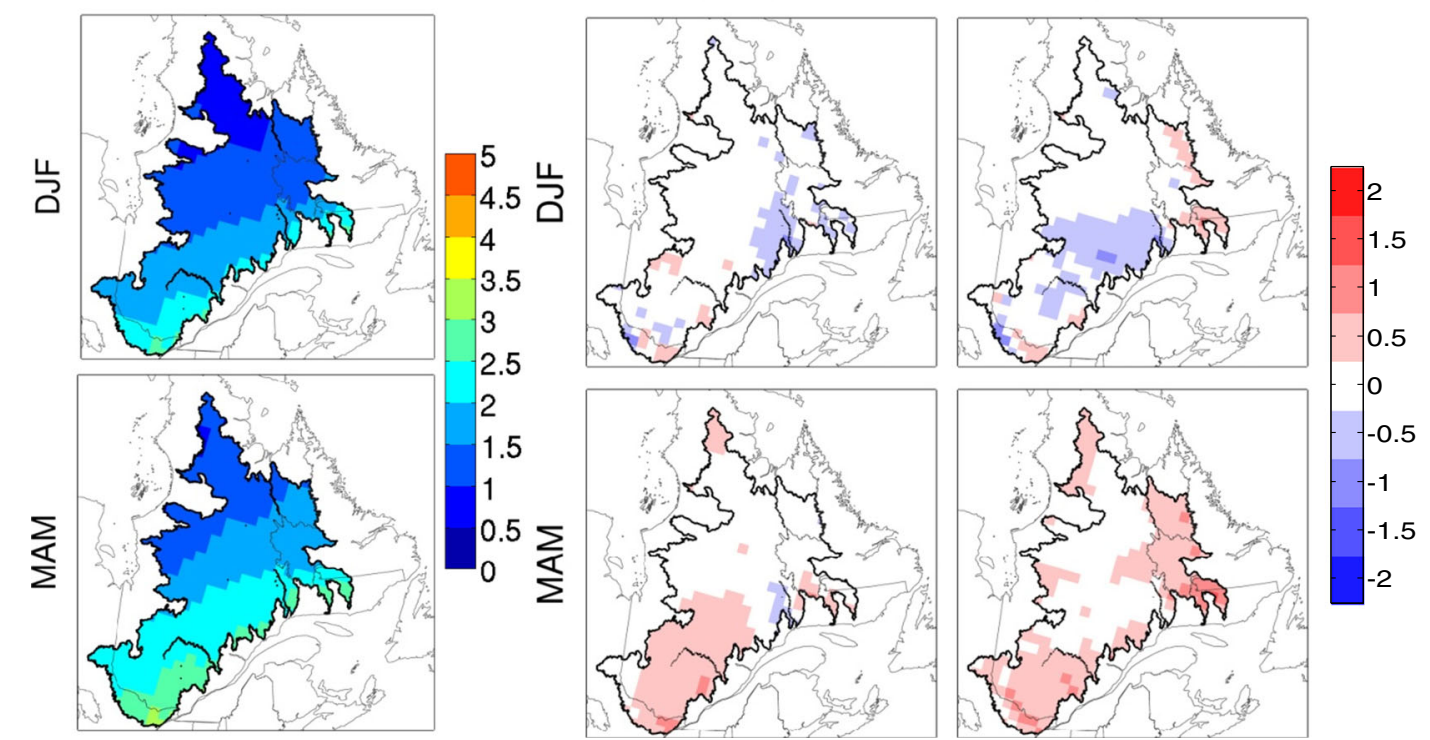

Fig. 2 Winter (DJF) and spring (MAM) a mean air temperature $\left({ }^{\circ} \mathrm{C}\right)$ and b precipitation $(\mathrm{mm} /$ day) from ERA-Interim (left column) and their comparisons with CRU (middle column) and UDEL (right column) for the 1990-2001 period

indicate regions where the differences between observed and simulated SWE are statistically significant at $5 \%$ significance level. The southern part of the study domain shows significant differences between simulated (EXP-1, EXP-2 and EXP-3) and observed (GlobSnow and $\mathrm{CMC}$ ) datasets. The warmer temperatures of ERA-Interim in comparison to CRU and UDEL (Fig. 2) could be one of the reasons for this SWE underestimation in the southern regions in the simulations. Comparison of EXP-2 and EXP-3 simulated SWE to that of EXP-1 (Fig. 3c) suggests no important differences in SWE in all these simulations. This would imply that any changes to streamflows in EXP-2 and EXP-3 compared with EXP-1 is generally not related to SWE changes but due to other mechanisms which are investigated below.

Since the hydraulic conductivity formulations differ in the three simulations, it is useful to start by looking at the spatial distribution of hydraulic conductivity and its impact on soil moisture over the study domain. Figure 4a shows the mean hydraulic conductivity for the study area for EXP-1 and differences between EXP-2/EXP-3 and EXP-1 for the May- 


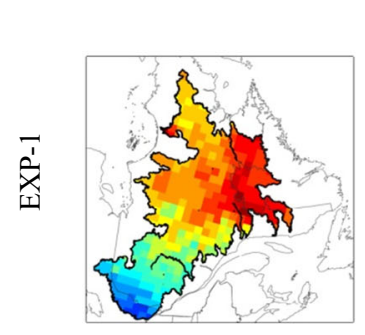

EXP-1 - GlobSnow

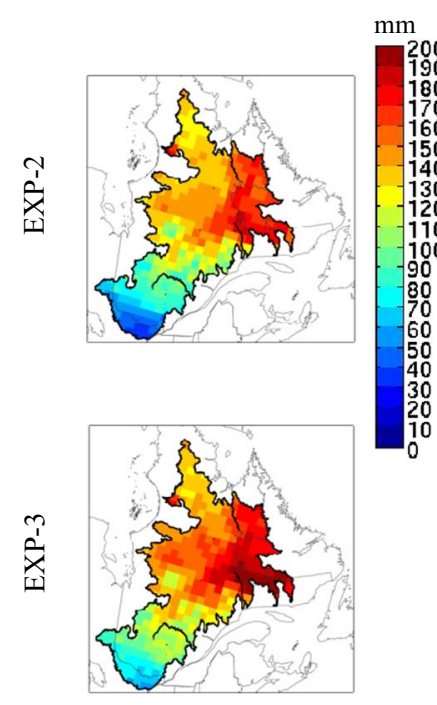

(a)

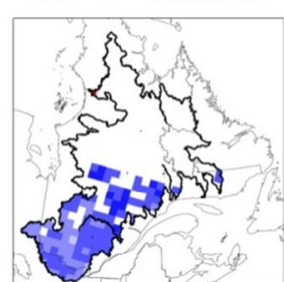

$\mathrm{mm}$

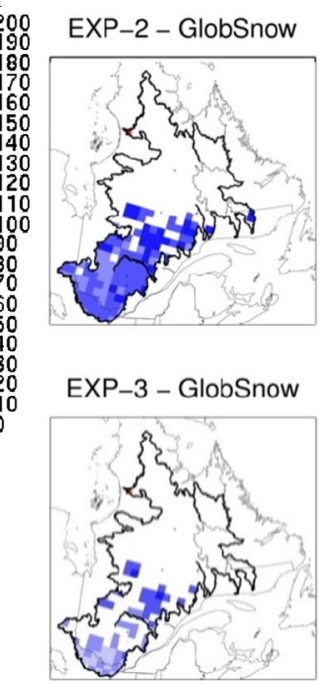

Fig. 3 a Maximum mean monthly snow water equivalent (SWE; mm) for the DJFMAM EXP-1, EXP-2 and EXP-3 and $\mathbf{b}$ their comparison with GlobSnow and the Canadian Meteorological Centre snow data sets. c

August months. These months are selected since the large differences are expected during these months, particularly around snowmelt when both frozen and liquid water content are reasonably large (depending on the location). In addition, analysis focuses on grid cells with bedrock situated at more than $10 \mathrm{~cm}$ below the surface, as impact of different hydraulic conductivity formulations would have a larger impact for these grid cells. As can be seen in Fig. 4a, EXP-3 hydraulic conductivities are smaller than those for EXP-1 during the snowmelt season (May-August) for central and southern parts of the study area, where bedrock is generally situated at below $3 \mathrm{~m}$ from the surface. For EXP-2, the hydraulic conductivity has been increased significantly for the southern and central parts of the study area. The reason for this increase in hydraulic conductivity is because of the hydraulic conductivity formulation used by Niu and Yang (2006) (Eq. (6)) which uses the total soil moisture content, instead of the liquid soil moisture content, in the original equation proposed by Clapp and Hornberger (1978).

Soil moisture is compared between EXP-2/EXP-3 and EXP-1 for the May-August period, when the snowmelt rate and surface runoff are high (Fig. 4b). Soil moisture varies with processes such as infiltration of snowmelt/precipitation and

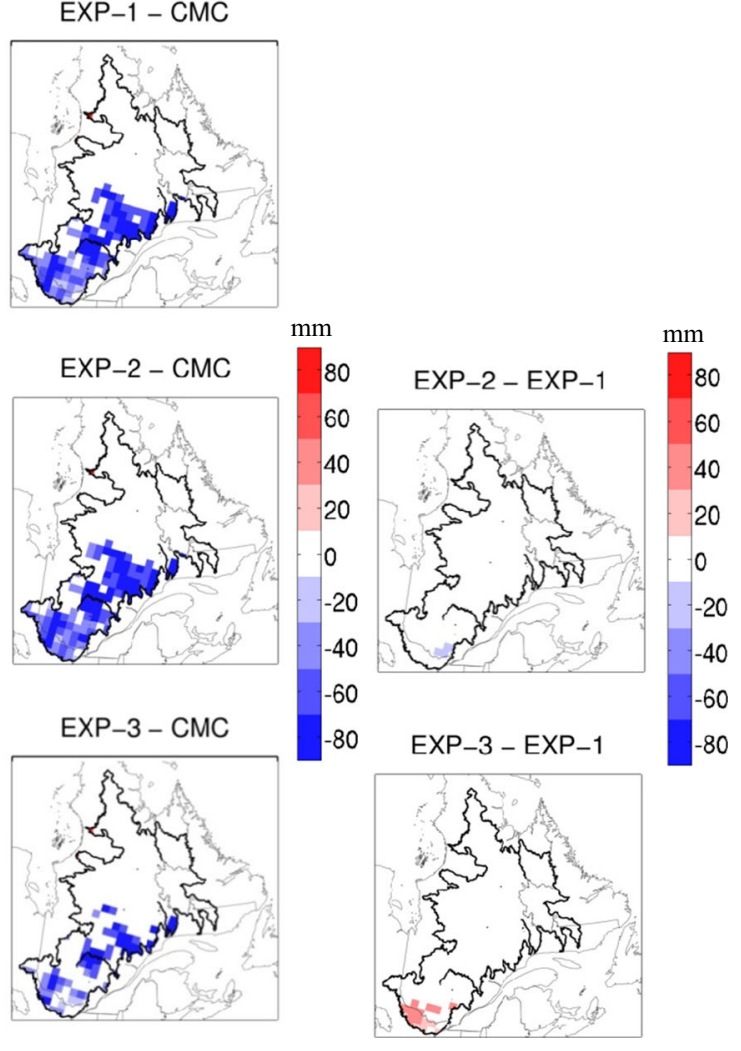

(b)

(c)

Comparison of EXP-2/EXP-3 SWE to that in EXP-1. In (b) and (c), only those grid cells with differences that are statistically significant at $95 \%$ confidence level are shown

contribution to subsurface flow in addition to evapotranspiration. Consistent with the lower hydraulic conductivity in EXP3, soil moisture is significantly low in EXP-3 compared to EXP-1 for most of the grid cells in the southern and central parts of study area. EXP-2, on the other hand, exhibits lower soil moisture compared to EXP-1 despite the higher hydraulic conductivity. The lower soil moisture content in EXP-2 is due to increased drainage in EXP-2, which is the result of smaller absolute values of soil moisture potential in EXP-2 (Eq. (7)).

To investigate the impact of implementing supercooled liquid water, the annual cycle of spatially averaged liquid water content is plotted in Fig. 5 for two basins, La Grande Riviere (LGR) and Bersimis-Outardes-Manic (BOM), situated in the central part of the domain. The liquid moisture content during the winter and early spring months is high for EXP-3 due to the inclusion of supercooled soil water (Eq. (11)) and higher absolute values of matric potential (see Eq. (9)). Though EXP-2 allows supercooled soil water, the liquid water content in this experiment is lower than that for EXP-1 due to increased drainage. During the snowmelt period, liquid water content is lowest for EXP-3 due to reduced infiltration as discussed earlier.

The surface runoff for EXP-1, EXP-2 and EXP-3 is compared in Fig. 6 for the snowmelt period, i.e. May-August. As 

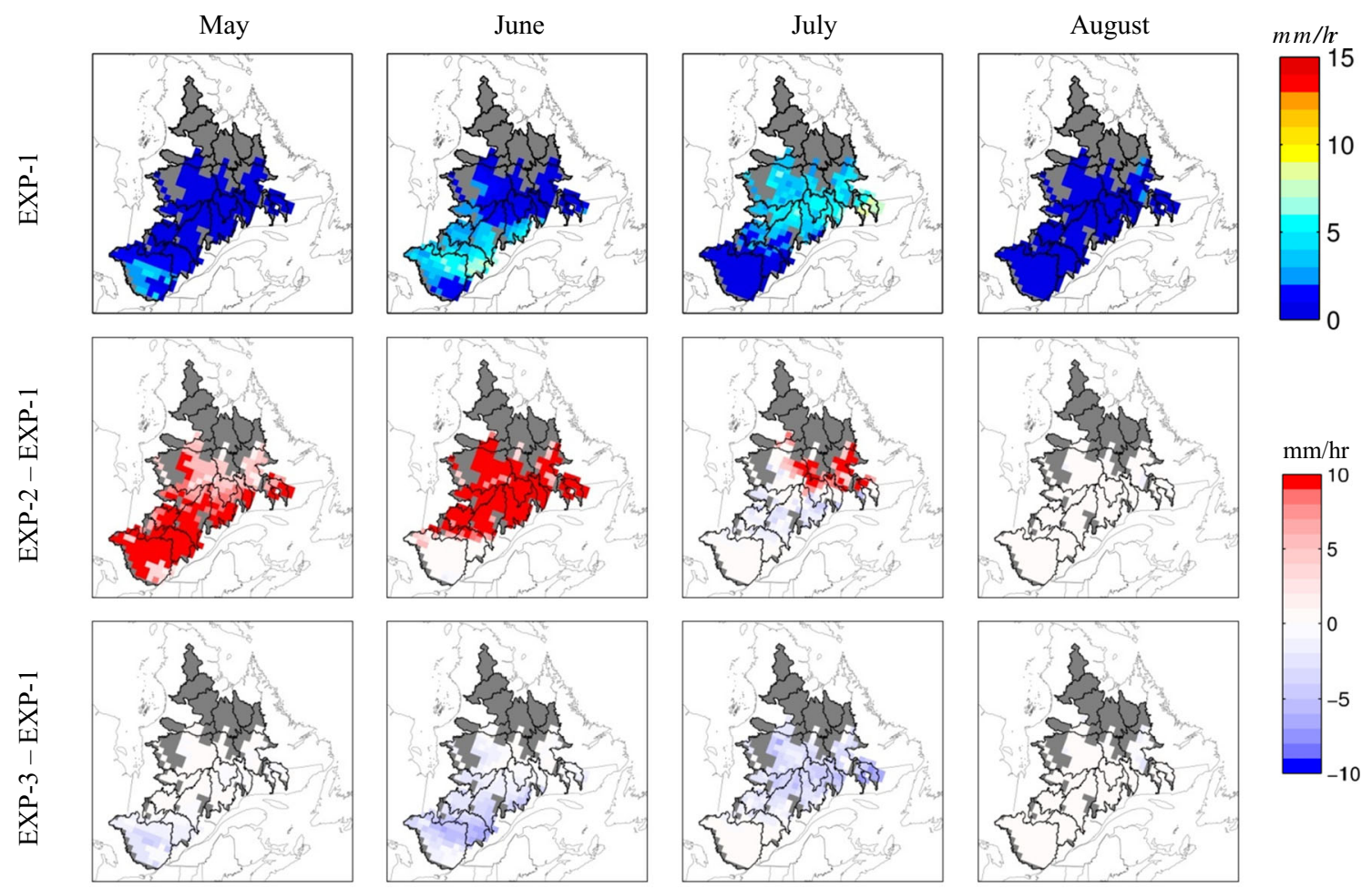

(a)
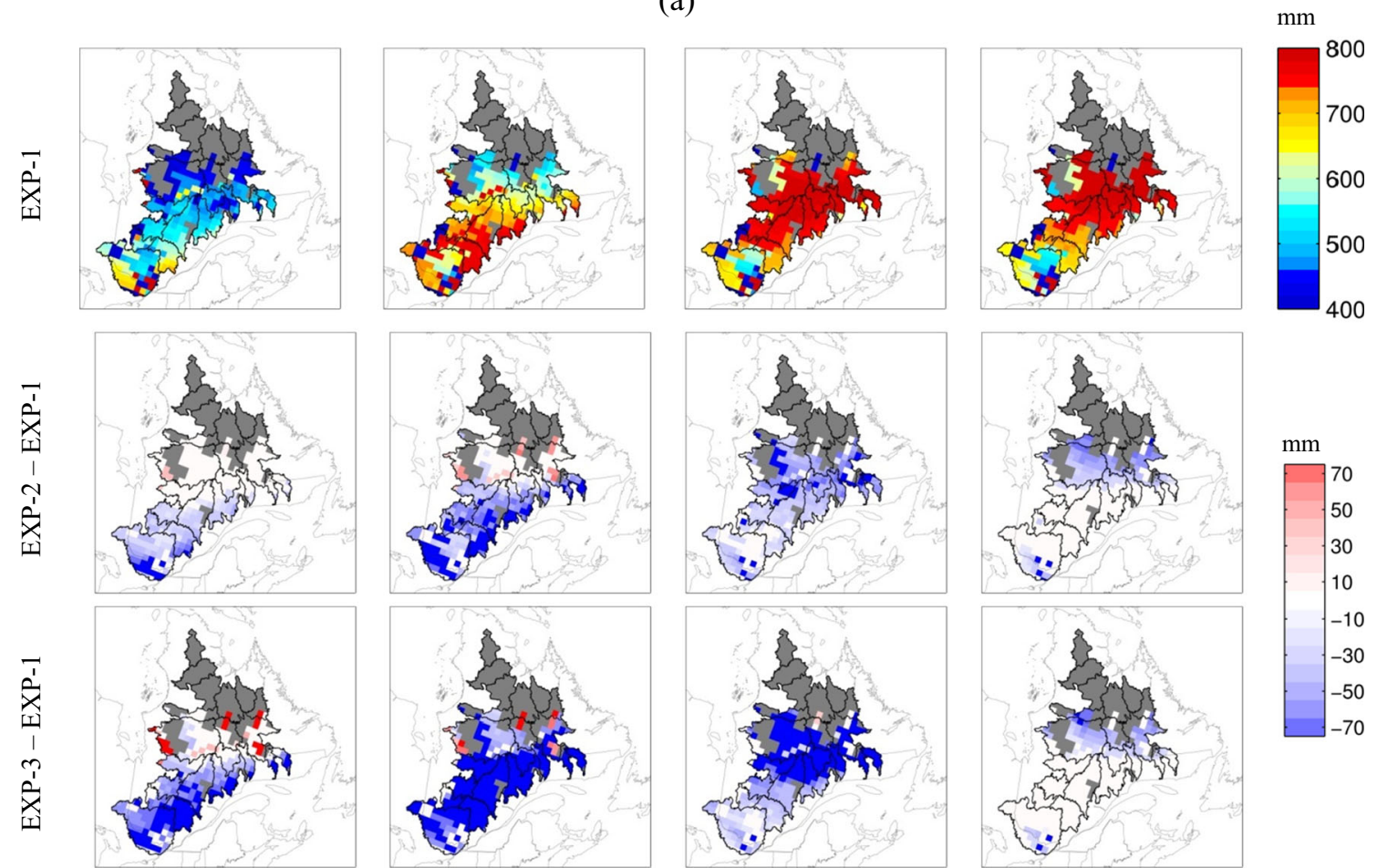

(b)

Fig. 4 The top panels of (a) and (b) show mean hydraulic conductivity $(\mathrm{mm} / \mathrm{h})$ and soil moisture $(\mathrm{mm})$ for the May-August months for EXP-1. The differences in hydraulic conductivity and soil moisture for the EXP-2 and EXP-3 simulations in comparison with EXP-1 are shown in the

expected, the simulated runoff shows maximum values migrating from south to north from May to August (left column

second and third rows of (a) and (b); grid cells, where the differences are not statistically significant at $95 \%$ confidence level are masked in white. Grid cells with bedrock situated at less than or equal to $10 \mathrm{~cm}$ from the surface are masked in grey in all figures

of Fig. 6 for EXP-1). The simulated runoff is higher in EXP-3 compared to EXP-1 (rightmost column of Fig. 6), particularly 

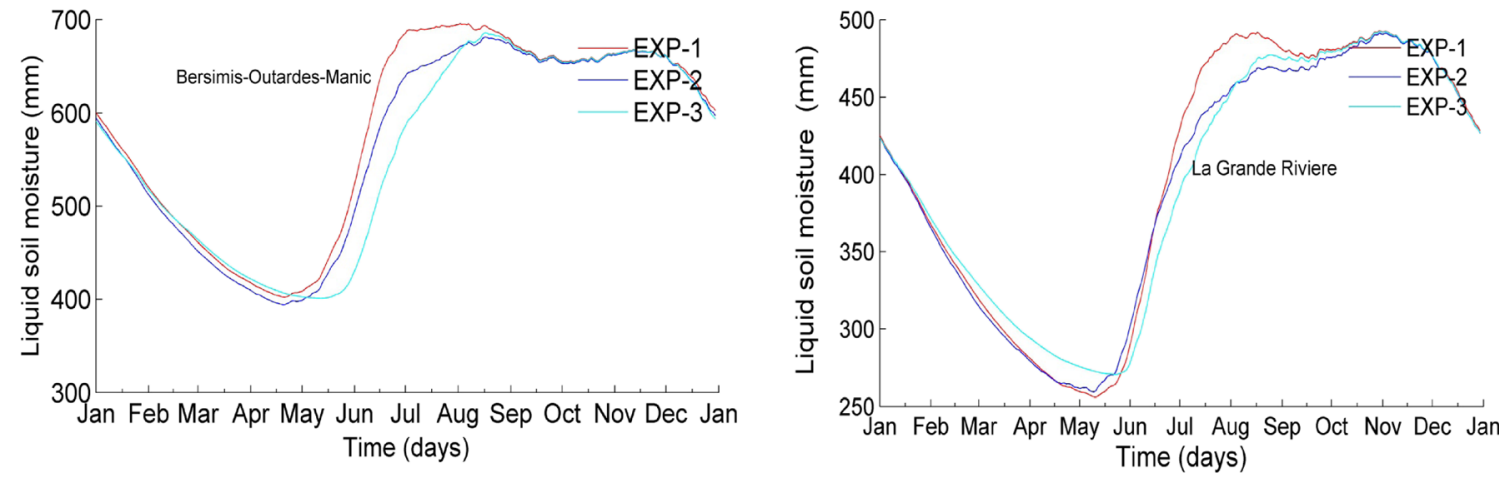

Fig. 5 Spatially averaged liquid soil moisture for two selected catchments (Bersimis-Outardes-Manic, BOM and La Grande Riviere, LGR) for EXP-1, EXP-2 and EXP-3

in the southern and central parts of the study domain, for the June and July months, respectively. The higher runoff values in EXP-3 are due to the lower hydraulic conductivity and therefore reduced infiltration, compared to EXP-1, leading to
EXP-1

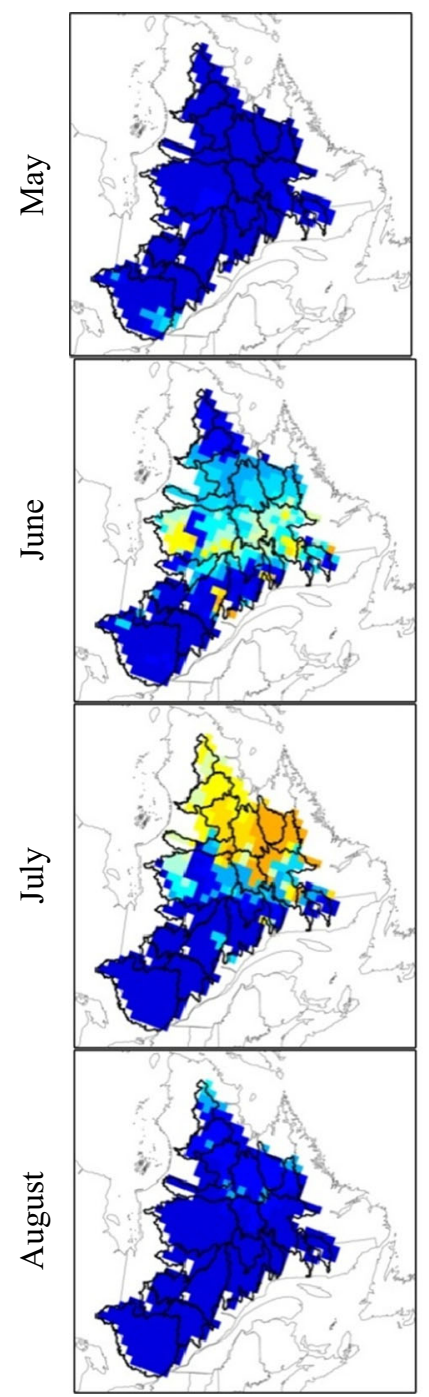

EXP-2 - EXP-1

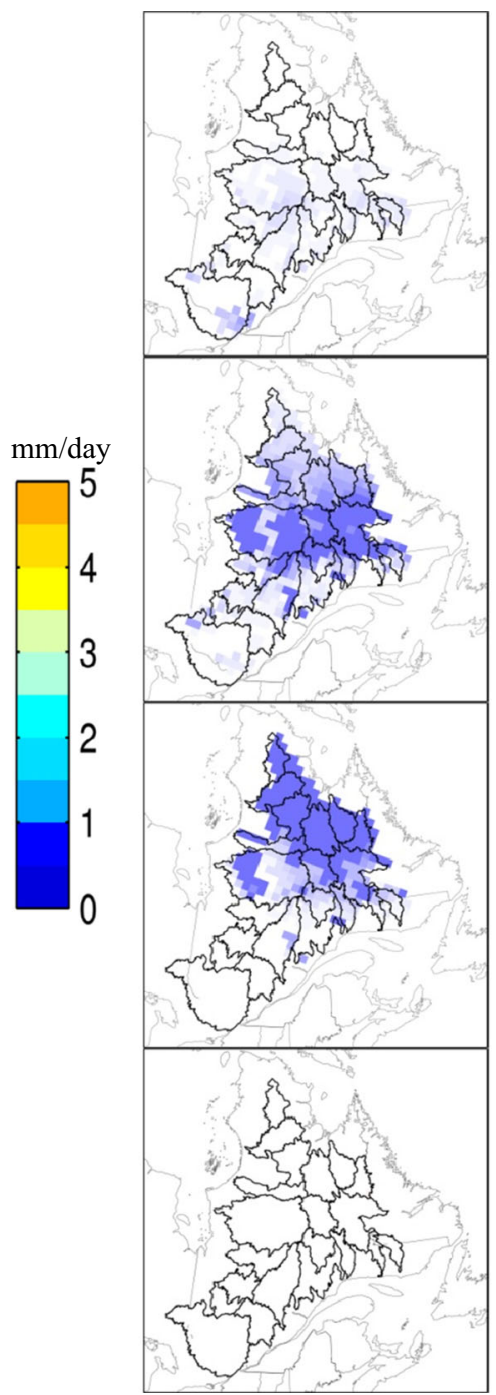

EXP-3 - EXP-1

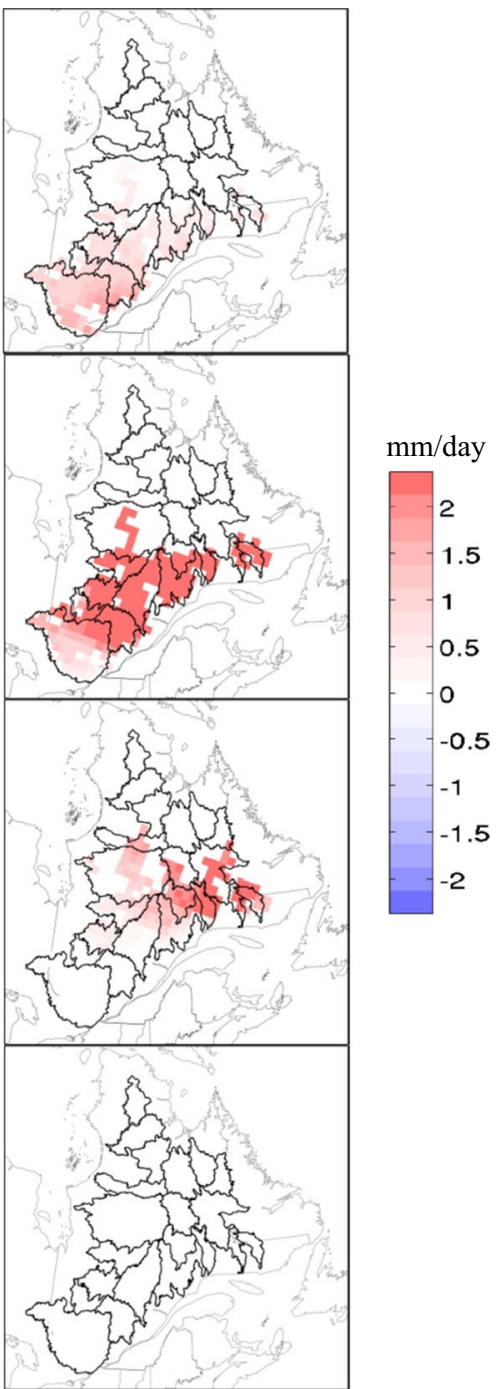

Fig. 6 Mean daily surface runoff ( $\mathrm{mm} /$ day) for the months of May, June, July and August for EXP-1 (left column) and the differences between EXP-2/EXP-3 and EXP-1 runoff (middle and right columns); grid cells where the differences are not statistically significant at $95 \%$ confidence level are masked in white 
larger fraction of snowmelt runoff. No significant differences are noted between EXP-3 and EXP-1 for the month of August as the hydraulic conductivity in both experiments is similar in unfrozen conditions. For EXP-2, runoff is significantly smaller than that for EXP-1 for the central and northern parts of the study area for the June and July months. This is due to the higher hydraulic conductivity of frozen soil in EXP-2 compared to EXP-1 which leads to more infiltration and therefore reduced surface runoff.

The simulated and observed mean annual hydrographs for EXP-1, EXP-2 and EXP-3 are compared at 6 selected gauging stations which are distributed across the study domain (Fig. 7). Figure 7 clearly shows that the timing and magnitude of spring peak flows have improved significantly in EXP-3 compared to EXP-1. Important differences, however, can be noted between EXP-3 and observed streamflows, particularly with the spring recession limb. This maybe related to the lack of representation of interflow and proper groundwater formulation in the model which is currently under investigation. Both EXP-1 and EXP-2 have larger biases, with a tendency to underestimate peak-flow values. As discussed earlier in Section 3.1, EXP-2 yields higher values of hydraulic conductivity for frozen soil conditions and therefore reduced streamflows.

The P-RMSE, PE and NS indices also show significant improvements in EXP-3 streamflows in comparison with EXP-1. The values of P-RMSE, NS and PE are improved for EXP-3 by 30, 80 and $38.9 \%$, respectively. Although prediction of low flow is still not perfect, these performance criteria show considerable reduction in peak error from using the modified treatment of frozen water in EXP-3. The average peak error for the study area is $28 \%$ for EXP-3, while it is $45 \%$ for EXP-1. Figure 8 shows box plots of daily streamflows that are higher than the 90th percentile daily flows for observations and simulations for the 12 locations shown in Fig. 1. The mean and variability of simulated extreme flows are closer to the observed values for EXP-3 for most of the locations. The box plots hint at small differences between observations and EXP-3 but these differences are not significant in most of the cases.

Given that the simulated streamflows are better for the EXP-3 case, the impact of the new formulations used in EXP-3 on other related surface hydrologic variables are now explored. To this effect, the annual cycle of surface water balance components simulated by CLASS (i.e. surface runoff, drainage or baseflow, soil moisture and evapotranspiration) for La Grande Riviere (LGR) and Bersimis-Outardes-Manic (BOM) basins are plotted in Fig. 9 for EXP-3 and EXP-1. The increase in surface runoff in EXP-3, compared to EXP-1, for the snowmelt period which was discussed earlier, is visible in the annual cycle of La Grande Riviere. However, since the drainage/baseflow in EXP-1 during the snowmelt season is larger than that for EXP-3, the differences in soil moisture is moderate, with EXP-3 having lower soil moisture. Although the differences in the mean monthly simulated evapotranspiration values are not obvious in Fig. 9, a maximum decrease of $2.2 \mathrm{~mm} /$ day is detected in the mean daily values of evapotranspiration for the month of May in EXP-3, associated with the slightly lower soil moisture content. In general, the Bersimis-Outardes-Manic basin shows similar differences as for La Grande between EXP-3 and EXP-1 (Fig. 9).

\section{Summary and conclusions}

Spring snowmelt peak flows in the high-latitude regions are often not realistically simulated by climate models, partly due to biases in the simulated temperatures and precipitation and partly due to deficiencies in the treatment of frozen water used in the land surface module of the climate model. In this paper, the sensitivity of simulated streamflows to selected modifications to the treatment of frozen water in the land surface model CLASS is investigated. Three offline experiments, EXP-1, EXP-2 and EXP-3, driven by ERA-Interim reanalysis, are performed with CLASS for the 1990-2001 period over a domain covering northeast Canada. Experiment EXP-1 is performed with the original version of CLASS, while EXP-2 and EXP-3 are performed with modified versions of CLASS. The fractional permeable area concept and supercooled liquid water are included in EXP-2 as in Niu and Yang (2006). This experiment also used the same hydraulic conductivity formulation proposed by Niu and Yang (2006). Experiment EXP-3 also includes fractional permeable area and supercooled liquid water but uses a more realistic formulation for soil matric potential and hydraulic conductivity. This yields lower hydraulic conductivity in EXP-3 compared to both EXP-1 and EXP-2.

Comparison of simulated streamflows to those observed at selected gauging stations suggests significant improvements in the magnitude and timing of spring peak flows in EXP-3. This is due to the reduced hydraulic conductivity of frozen soil in EXP-3, which leads to higher snowmelt runoff and smaller infiltration, which is reflected also in the reduced soil moisture content compared to EXP-1. EXP-2, on the other hand, it further reduces spring flows compared to EXP-1 due to the higher frozen soil hydraulic conductivity, leading to increased infiltration. However, the soil moisture does not increase in EXP-2 compared to EXP-1, despite the increase in infiltration. Analysis shows that this is due to the smaller absolute matric soil potential in EXP-2, which leads to increased drainage. Various statistical criteria considered to compare the experiments clearly suggest improved simulation of the timing and magnitude of spring peak flows in EXP-3. From the analysis performed in this study, it can be concluded that using a more realistic treatment of frozen water seems indispensable for simulating streamflows for high-latitude regions. 

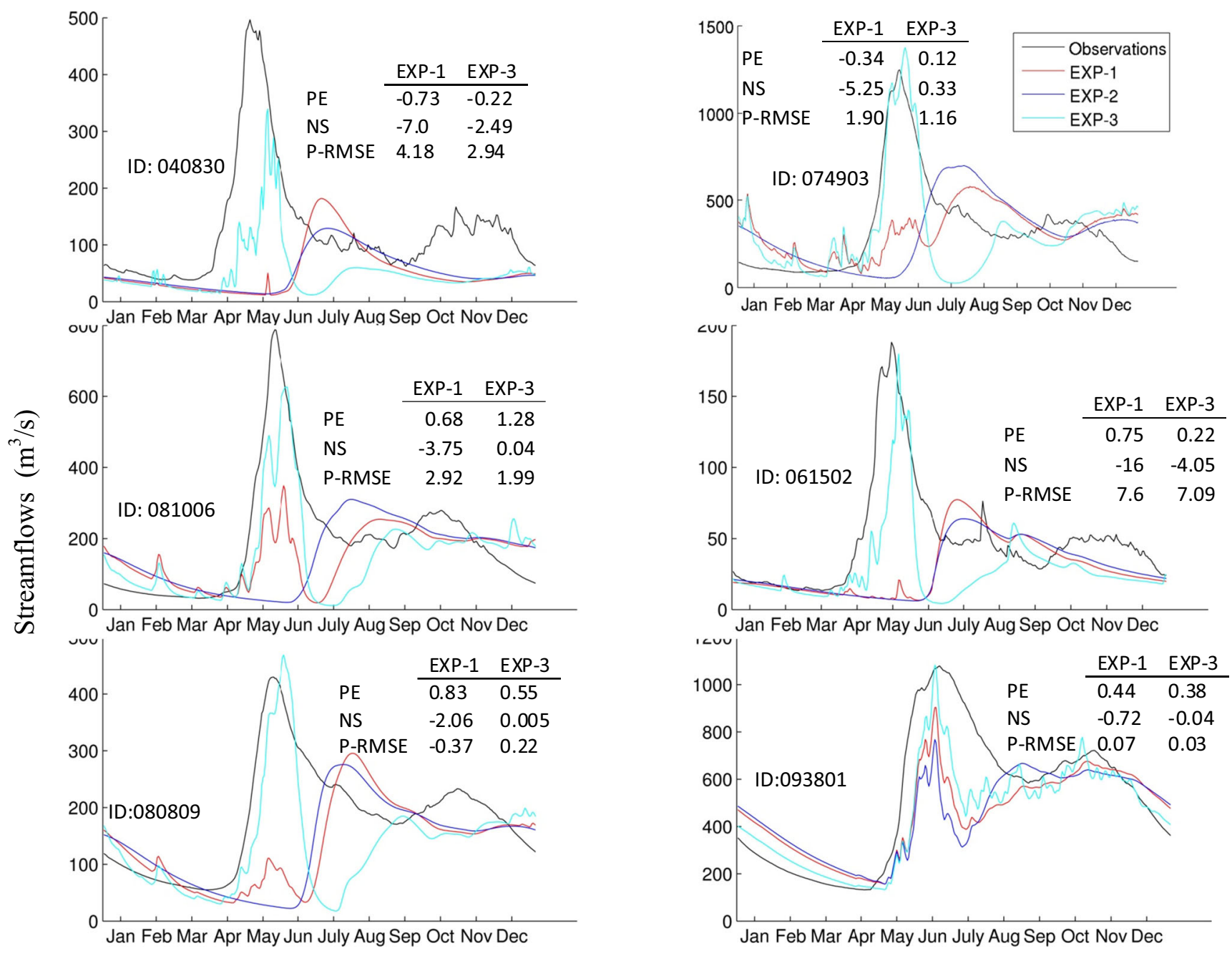

\section{Time (months)}

Fig. 7 Comparison of observed and simulated hydrographs at six gauging stations; station IDs are indicated and corresponding details are provided in Table 1. The P-RMSE, PE and NS values are also indicated on each subplot

Experiment EXP-3, however, does not capture well the spring recession limb of the hydrograph and low flows in general. This can be improved through better presentation of hydrologic processes, such as surface-groundwater interaction in CLASS. Currently, the lower boundary condition is set to gravitational drainage in CLASS. Studies by Niu et al. (2007) and Yuan and Liang (2011) have shown the need to have improved representation of surface watergroundwater interactions to simulate better the soil moisture content and baseflow contributions to streamflows. Furthermore, significant proportion of streamflow contribution comes from lateral runoff or interflow in the case of summer storms (Letts et al. 2010). Interflow has not been included in the experiments presented in this study. Lack of interflow can partly explain the lower than observed streamflows in the simulations for the post snowmelt and summer seasons. Frampton et al. (2011) clearly demonstrates the important role of lateral flows and groundwater on streamflows. Inclusion of interflow and a groundwater component in CLASS is currently underway and this is expected to further improve CLASS-simulated runoff and streamflows for high-latitude regions. The simulations considered in this study did not include lakes and wetlands, which are also important for realistic simulation of streamflows. Furthermore, since CLASS uses a single layer representation of the snowpack, our future work will also focus on the inclusion of a multi-layer snow model in CLASS.

Though the formulations in EXP-3 improved spring flows in offline CLASS simulations, experiments will need to be conducted with the regional climate model with modified 


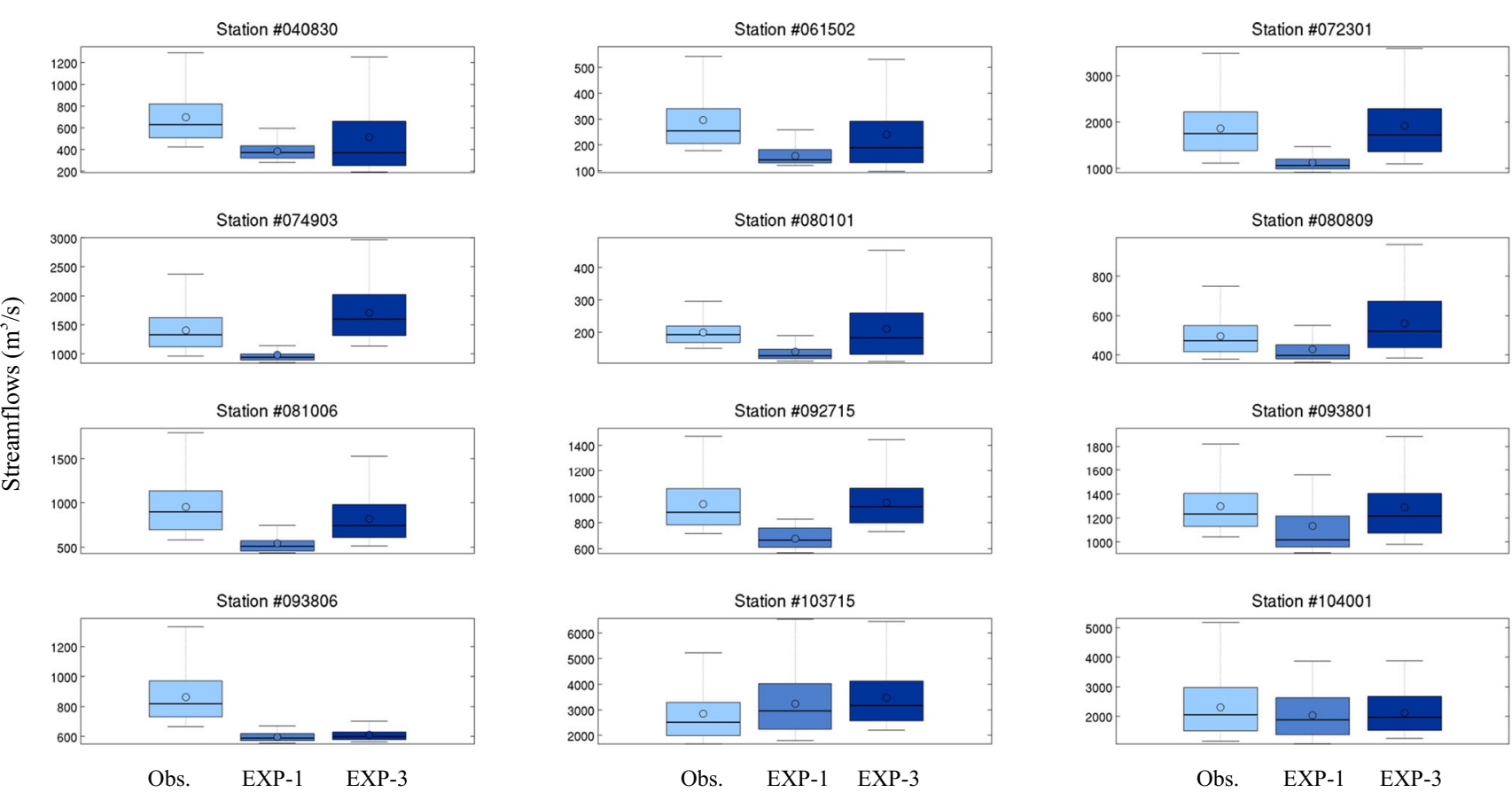

Fig. 8 Box plots of daily streamflows larger than the 90th percentile for observed and simulated streamflows for EXP-1 and EXP-3 at the 12 selected gauging stations shown in Fig. 1

CLASS to see the impact of the modifications on streamflows in the coupled simulation since land-atmosphere interactions can lead to different results than those obtained in the offline simulations. The expectation is that the results would still hold

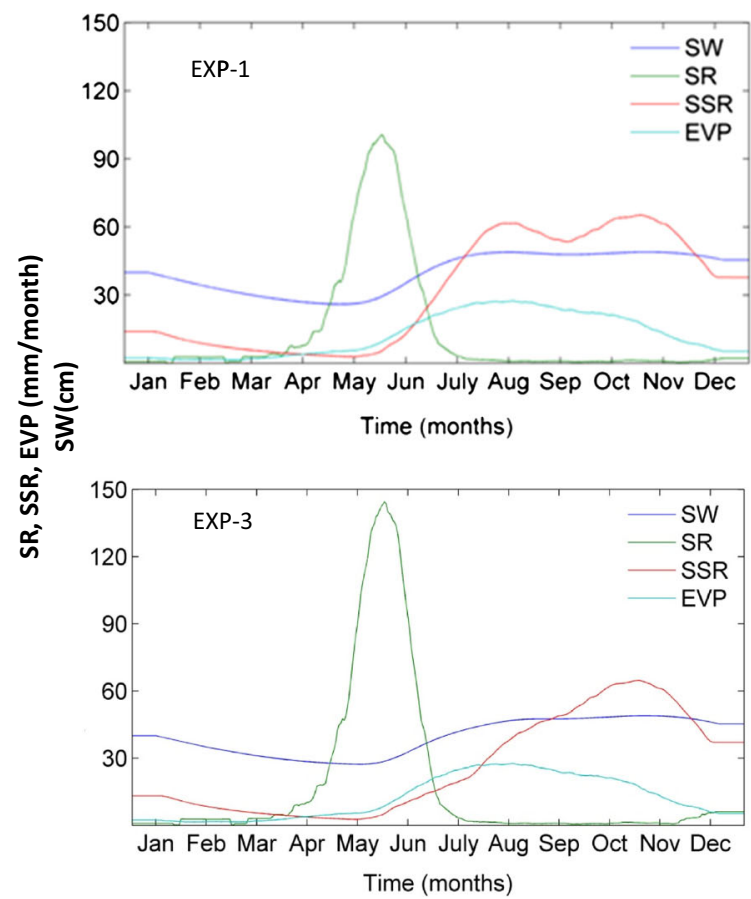

(a)
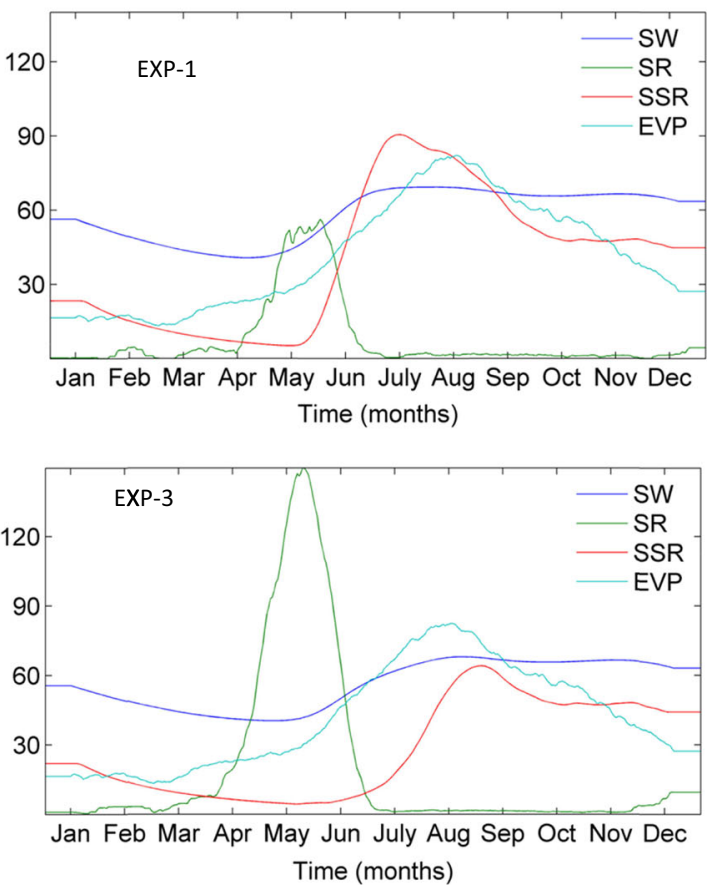

(b)

Fig. 9 Mean annual cycle of selected hydrologic variables for a La Grande (LGR) and b Bersimis-Outardes-Manic watersheds (BOM) for EXP-1 and EXP-3. Surface runoff (SR; mm/month), drainage (SSR; mm/month), evapotranspiration (EVP; $\mathrm{mm} / \mathrm{month}$ ) and total soil moisture (SW; $\mathrm{cm}$ ) 
since land-atmosphere interactions are generally weaker during the early phase of the snowmelt period.

\section{Appendix I}

Campbell (1974) showed that the hydraulic conductivity can be estimated using a moisture retention function (Eq. (15)), assuming that the pore size distribution function $(F(r))$ to be the same throughout the porous body;

$K_{i}=M \int_{0}^{R} \int_{0}^{R} r^{2} F(r) d r F(r) d r$

where $R$ is the radius of the largest water-filled pore and $r$ is the pore radius and can be determined using the capillary rise equation as:

$r=-\frac{2 \gamma}{\psi}$

where $\psi$ is the matric potential. Using Eq. (8) for the matric potential in frozen soil,

$r=-\frac{2 \gamma}{\psi}\left(\frac{\theta_{\text {liq }}}{\theta_{\text {sat }}}\right)^{\mathrm{b}}\left(1+C_{k} \theta_{\text {ice }}\right)^{-2}$

where $\theta_{\text {liq }}$ and $\theta_{\text {sat }}$ are the liquid water content and soil porosity, respectively. Substitution of this expression in Eq. (15) gives:

$K_{i}=C \cdot\left(1+C_{k} \theta_{\mathrm{ice}}\right)^{-4} \iint_{0}^{\theta} \theta_{\mathrm{liq}}^{2 b} \cdot d \theta_{\mathrm{liq}} \cdot d \theta_{\mathrm{liq}}$

where $C$ is a constant which is defined as:

$C=-M\left(\frac{2 \gamma}{\psi}\left(\frac{\theta_{\text {liq }}}{\theta_{\text {sat }}}\right)^{b}\right)^{2}$

Integration between limits gives:

$K_{i}=C^{\prime} \cdot\left(1+C_{k} \theta_{\text {ice }}\right)^{-4} \theta_{\text {liq }}^{2 b+2}$

where $C^{\prime}$ includes constants from Eq. (19) and integration. $C^{\prime}$ is given by $C^{\prime}=\frac{K_{s}}{\theta_{\text {sat }}^{b+2}}$ for $\theta_{\text {ice }}=0, \quad \theta_{\text {liq }}=\theta_{\text {sat }}$

The hydraulic conductivity can then be estimated as

$K=\frac{K_{s}}{\left(1+C_{k} \theta_{\text {ice }}\right)^{4}} \cdot\left(\frac{\theta_{\text {liq }}}{\theta_{\text {sat }}}\right)^{2 b+3}$

Comparing with Campbell's equation, Eq. (21) reduces the hydraulic conductivity by a factor of $\left(1+C_{k} \theta_{\text {ice }}\right)^{-4}$. Equation (21) compared to Eq. (2) yields ice content factor

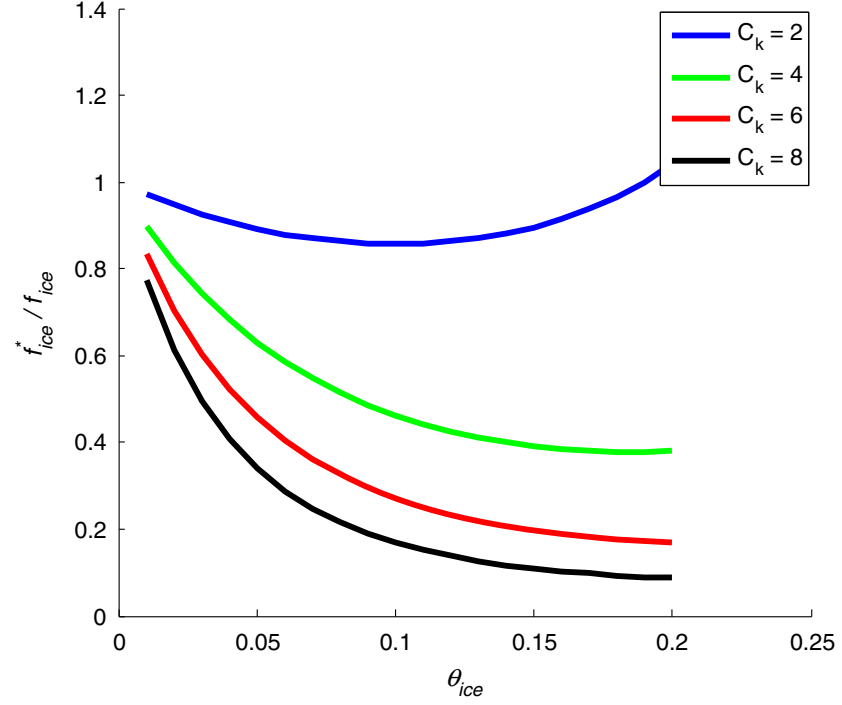

Fig. 10 The ratio of $f_{\text {ice }}$ based on Eq. (22) to that based on Eq. (2) for different values of $C_{k}$ and frozen water contents

$f_{\text {ice }}^{*}=\left(1+C_{k} \theta_{\text {ice }}\right)^{-4}$

The ratio of $f_{\text {ice }}$ based on Eq. (22) to that based on Eq. (2) for different values of $C_{k}$ and frozen water contents is shown in Fig. 10.

Open Access This article is distributed under the terms of the Creative Commons Attribution 4.0 International License (http:// creativecommons.org/licenses/by/4.0/), which permits unrestricted use, distribution, and reproduction in any medium, provided you give appropriate credit to the original author(s) and the source, provide a link to the Creative Commons license, and indicate if changes were made.

\section{References}

Bayard D, Stähli M, Parriaux A, Fluhler H (2005) The influence of seasonally frozen soil on snowmelt runoff at two alpine sites in southern Switzerland. J Hydrol 209:66-84

Brown R, Brasnett DB (2010) Canadian meteorological centre (CMC) daily snow depth analysis data. National Snow and Ice Data Center, Boulder

Campbell GS (1974) A simple method for deterministic unsaturated conductivity from moisture retention data. J Soil Sci 117:311-314

Cherkauer KA, Lettenmaier DP (2003) Simulation of spatial variability in snow and frozen soil. J Geophys Res 108(D22):8858

Clapp RB, Hornberger GM (1978) Empirical equations for some soil hydraulic properties. Water Resour Res 14:601-604

Das T, Bardossy A, Zehe E, He Y (2008) Comparison of conceptual model performance using different representations of spatial variability. J Hydrol 356:106-118

Dee et al (2011) The ERA-interim reanalysis: configuration and performance of the data assimilation system. J R Meteorol Soc 137(656): 553-579

Farkouki OT (1981) The thermal properties of soils in cold regions. Cold Reg Sci Technol 5:67-75 
Food and Agriculture Organization of the United Nations (2006) World reference base for soil resources, a framework for international classification, world soil resources reports, No. 103. FAO, Rome

Frampton A, Painter S, Lyon SW, Destouni G (2011) Non-isothermal, three-phase simulations of near-surface flows in a model permafrost system under seasonal variability and climate change. J Hydrol 403(3-4):352-359

Hundecha Y, Zehe E, Bardossy A (2007) Regional parameter estimation from catchment properties prediction in ungauged basins, Predictions in Ungauged Basins: PUB Kick-off (Proceedings of the PUB Kick-off meeting held in Brasilia, 20-22 November 2002). IAHS Publ. 309

Huziy O, Sushama L, Khaliq MN, Laprise R, Lehner B, Roy R (2012) Analysis of streamflow characteristics over north-eastern Canada in a changing climate. Clim Dyn 40(7-8):1879-1901

Koren V, Schaake J, Mitchell K, Duan QY, Chen F, Baker JM (1999) A parameterization of snowpack and frozen ground intended for NCEP weather and climate models. J Geophys Res 104(D16): 19569-19585

Kulik VY (1978) Water infiltration into soil (in Russian). Gidrometeoizdat, $93 \mathrm{pp}$

Lehner B, Verdin K, Jarvis A (2008) New global hydrography derived from spaceborne elevation data. Eos Trans AGU 89(10):93-99

Letts MG, Roulet NT, Comer NT, Skarupa MR, Verseghy DL (2010) Parameterization of peatland hydraulic properties for the Canadian land surface scheme. Atmosphere-Ocean 38(1):141-160

Lindstrom G, Bishop K, Lofvenius MO (2002) Soil frost and runoff at Svartberget, northern Sweden - measurements and model analysis. Hydrol Process 16:3379-3392

Luojus K, Pulliainen J, Takala M, Lemmetyinen J, Dersken C, Wang L (2010) Global Snow Monitoring for Climate Research-Snow Water Equivalent (SWE) product guide, European Space Agency: 15. ESRIN Contract 21703/08/I-EC

Luthdin L (1990) Hydraulic properties in an operational model of frozen soil. J Hydrol 118(1-4):289-310

Martynov A, Laprise R, Sushama L, Winger K, Šeparović L, Dugas B (2013) Reanalysis-driven climate simulation over CORDEX North America domain using the Canadian regional climate model, version 5: model performance evaluation. Clim Dyn 41(11-12):2973-3005

Mitchell TD, Jones PD (2005) An improved method of constructing a database of monthly climate observations and associated highresolution grids. Int J Climatol 25:693-712

Nash JE, Sutcliffe JV (1970) River flow forecasting through conceptual models part I, a discussion of principles. J Hydrol 10(3):282-290

Niu GY, Yang ZL (2006) Effects of frozen soil on snowmelt runoff and soil water storage at a continental scale. J Hydrometeorol 7(5):937-945
Niu GY, Seo KW, Yang ZL, Wilson C, Su H, Chen J, Rodell M (2007) Retrieving snow mass from GRACE terrestrial water storage change with a land surface model. Geophys Res Lett 34(15), L15704

Nyberg L, Stähli M, Mellander PE, Bishop K (2001) Soil frost effects on soil water and runoff dynamics along a boreal forest transact: 1 . Field investigations. Hydrol Process 15:909-926

Poitras V, Sushama L, Seglenieks F, Khaliq MN, Soulis E (2011) Projected changes to streamflow characteristics over western Canada as simulated by the Canadian RCM. J Hydrometeorol 12: 1395-1413

Shanley JB, Chalmers A (1999) The effect of frozen soil on snowmelt runoff at Sleepers river, Vermont. Hydrol Process 13:1843-1857

Soulis ED, Snelgrove KR, Kouwen N, Seglenieks F, Verseghy DL (2000) Towards closing the vertical water balance in Canadian atmospheric models: coupling of the land surface scheme CLASS with the distributed hydrological model WATFLOOD. Atmosphere-Ocean 38(1):251-269

Spaans EJA, Baker JM (1996) The soil freezing characteristics: its measurement and similarity to the soil moisture characteristics. Soil Sci Soc Am J 60:13-19

Stähli L, Nyberg PE, Mellander PE, Bishop KH (2001) Soil frost effects on soil water and runoff dynamics along a boreal forest transact: 2 . Simulations. Hydrol Process 15:927-941

Sushama L, Laprise R, Caya D, Larocque M, Slivitzky M (2004) On the variable-lag and variable-velocity cell-to-cell routing schemes for climate models. Atmosphere-Ocean 42(4):221-233

United States Army Corps of Engineers (2000) Hydrological modelling system HEC-HMS, technical reference manual. United States Army Corps of Engineers, USA, 150 pp

Verseghy D (2012) CLASS - The Canadian Land Surface Scheme (Version 3.6) Technical Documentation. $179 \mathrm{pp}$

Verseghy DL, McFarlane NA, Lazare M (1993) CLASS - a Canadian land surface scheme for GMCs II. Vegetation model and coupled runs. Int J Climatol 13:347-370

Webb RS, Rosenzweig CE, Levine ER (1991) A global data set of soil particle size properties. NASA Tech Memo 4286, $34 \mathrm{pp}$

Willmott CJ, Matsuura K (1995) Smart interpolation of annually averaged air temperature in the United States. J Appl Meteorol 34:25772586

Yuan X, Liang XZ (2011) Evaluation of a conjunctive surface-subsurface process model (CSSP) over the contiguous United States at regionallocal scales. J Hydrometeorol 12(4):579-599

Zhao L, Gray DM (1997) A parametric expression for estimating infiltration into frozen soils. Hydrol Process 11:1761-1775 